\title{
INTERNAL MIGRATION PATTERNS OF FOREIGN-BORN IMMIGRANTS IN SPAIN A study based on the National Immigrant Survey (ENI-2007)
}

\author{
LA MOVILIDAD INTERNA DE LOS INMIGRANTES EN ESPAÑA \\ Un estudio basado en la Encuesta Nacional de Inmigrantes (ENI-2007)
}

DAVID ReHER dreher@geps.es

Universidad Complutense de Madrid y Grupo de Estudios "Población y Sociedad". España.

JAVIER Silvestre javisi@@unizar.es

Universidad de Zaragoza y Grupo de Estudios "Población y Sociedad". España.

\begin{abstract}
This article extends the existing literature on the internal migration patterns of the foreign-born in Spain. We analyze the spatial distribution of immigrants and their patterns of mobility at different levels. Socio-demographic characteristics of immigrants and characteristics of places of origin and destination are considered. We also examine repeat migration, duration of residence in each destination, as well as return migration within Spain. To this end, we make use of a new micro database corresponding to the National Immigrant Survey (Encuesta Nacional de Inmigrantes, ENI-2007).
\end{abstract}

\section{KEYWORDS}

Descriptive Analysis, Immigration in Spain, Internal migration patterns of the foreign-born, National Immigrant Survey.

\section{RESUMEN}

Este artículo contribuye a la literatura sobre la migración interna de los inmigrantes nacidos fuera de España. En él se analiza la distribución espacial y las pautas de movilidad de los inmigrantes, considerando aspectos como las características sociodemográficas de los individuos y las características de los orígenes y destinos dentro de España. También se analiza la emigración repetida, la duración de la residencia en cada destino y la emigración de retorno (dentro de España). Para todo ello, se utiliza la nueva base de datos micro derivada de la Encuesta Nacional de Inmigrantes, ENI-2007.

\section{Palabras Clave}

Inmigración en España, Movilidad interna de los inmigrantes, Análisis descriptivo, Encuesta Nacional de Inmigrantes (ENI-2007). 


\section{INTRODUCCIÓN ${ }^{1}$}

Most European nations have experienced important immigration over the past two decades. This phenomenon was, to a large extent, the result of a need for labor throughout Europe (Hooghe et al. 2008). Spain, which had been a predominantly emigrant country until the late 1970s, has not been an exception to this process (see, for example, Massey et al. 1998; Venturini 2004). In fact, during the first years of the 21st Century (at least until the recent economic crisis) Spain became one of the main destinations both in Europe and worldwide (United Nations 2006; Dolado y Vázquez 2007; International Organization for Migration 2008).

The evolution of immigration to Spain can be divided into three general periods (Izquierdo 1996; Arango 2004; Cachón 2006). Until 1985 the majority of immigrants were employees of European multinational corporations or retirees, followed by political exiles from Latin America. The number and variety of immigrants from Latin America, North Africa, Eastern Europe and, though lesser, Asia increased gradually between 1985 and the end of the 20th Century. Despite this, the massive increase of immigration as well as its social, political and economic repercussions actually took place during the first years of the 21st century. Currently, immigration has become a "structural" characteristic of Spanish society.

One of the most visible aspects of immigration is the spatial distribution and/or the mobility of immigrants who have reached the host society. The analysis of internal migration of immigrants (movements within any given country) provides information about three traditional themes present on migration research agendas: its causes, its impact on the host country and the process of integration and assimilation of immigrants themselves. In the first place, it is important to bear in mind that international immigrants are a special group insofar as they have already undertaken at least one migratory move (Nogle 1994). Secondly, gathering reliable information on the migratory trajectories of immigrants is important when designing policy regarding population, society and the economy in host countries (for example, Bartel, 1989; Chiswick and Miller 2004). Finally, it has been shown that spatial mobility can become a migrant strategy used to accelerate or alter a person's process of integration into the new country (for example, see Massey 1985; Alba and Nee 1997; Iceland 2009).

In this article the spatial distribution and internal mobility of foreign-born immigrants to Spain is studied. This paper contributes to the existing specialized literature on the subject with a detailed analysis of patterns of mobility based on the microdata taken

\footnotetext{
${ }^{1}$ We would like to thank Maria Isabel Sánchez Domínguez and especially Patricia Pérez Cubillo for their able assistance with the ENI database. This research was funded by the grants from the Ministerio de Educación (SEJ2005-02396/SOCl) and from the Ministerio de Ciencia y Tecnología (CSO2008-03616/ SOCl).
} 
from the National Immigrant Survey (ENI-2007). ${ }^{2}$ The article is organized in the following way. In the next section, a brief literature review referring to this subject in Spain will be undertaken. In the subsequent sections, a descriptive analysis will be carried out on the socio-demographic characteristics of immigrants, the main patterns of their internal mobility (origin/destination) and the typology and frequency of repeat internal migrations. The article finishes with a section summarizing the main conclusions.

\section{THE INTERNAL MOBILITY OF IMMIGRANTS IN SPAIN. A BRIEF REVIEW OF THE LITERATURE}

The existing bibliography on spatial distribution and patterns of mobility among immigrants is most abundant in the United States, followed by Canada and Australia. Studies of this subject in European countries are much less frequent. Understandably, the existing literature on this subject in Spain is not abundant because in comparison to other countries mass immigration to Spain is a comparatively recent phenomenon. The main conclusions obtained from these studies on Spain can be summarized as follows: ${ }^{3}$

a) International immigrants show a propensity to move within Spain that is three or four times higher than that of natives.

b) The spatial concentration of immigrants is different from that of natives. Despite this, it is also clear that a large number of immigrants live in the four Autonomous Regions (Madrid, Catalonia, Valencia and Andalusia) where most of the Spanish population lives. In addition, the degree to which (and the way) immigrants concentrate spatially varies according to their country of origin.

c) The debate regarding the causes of internal migration in Spain remains open, in the sense that the importance of migration networks or economic factors, practically the only causes analyzed so far, may vary according to the study used. ${ }^{4}$

\footnotetext{
${ }^{2}$ The main characteristics of the Encuesta Nacional de Inmigrantes 2007 (sample size, sampling techniques, representativeness, fieldwork, limitations, etc), as well as its main advantages with respect to other existing datasets, are explained in Reher et al. (2008) and Reher y Requena (2009), as well as in the rest of the articles included in this special issue of the Revista Internacional de Sociologia. The webpage of the Spanish Statistical Office (Instituto Nacional de Estadística) (www.ine.es) includes additional information as well as the micro database itself.

${ }^{3}$ From the ample data offered by these studies, we highlight here the conclusions that are close to the main focus of this present article. We will return to this subject later on. The publications consulted are: Recaño (2002, 2004, 2008), García Coll (2005), Lamela (2006), Martínez Buján and Villares (2006), Recaño and Domingo (2006), Recaño and Roig (2006), Ródenas and Martí (2006), Dolado and Vázquez (2007), López Trigal (2008) and Martí and Ródenas (2008).

${ }^{4}$ The existence of migration networks is normally considered to be based on the shared social capital of its members. According to Alejandro Portes (1995: 12), social capital refers to "the capacity of individuals to command scarce resources by virtue of their membership in networks or broader social structures".
} 
In this sense, the recent paper by Reher and Silvestre (2009), based on the National Immigrant Survey 2007 (henceforth, ENI) introduces some variations with respect to the studies mentioned earlier. In the first place, and with respect to the type of data used, the ENI has the distinct advantage of including all types of internal movement, including moves within a given province, and refers to "non-natives" rather than to "foreigners". Secondly, the vast amount of individual data offered by the ENI enables the authors to empirically test the main theories explaining the propensity to move (within the host country) of immigrants. The main results of this study show how the accumulation of human capital, in the form of formal education and knowledge of Spanish, provides an important incentive for internal mobility among immigrants. ${ }^{5}$ mmigrants with higher incomes, on the other hand, are less likely to move, though it was also shown that a certain minimum level of income is necessary for internal movement. ${ }^{6}$ The impact of migration networks on the propensity to move is more noticeable when based on family members and less so in the case of networks made up of friends and acquaintances.

Other results included in Reher and Silvestre (2009), for example, show that the longer an immigrant has been residing in Spain, the greater the propensity to internal migration. This result underscores the importance of acquiring information regarding the labor market and the host society. Moreover, the propensity to move, once we control for the rest of the variables in the model, is strongly influenced by the world region of birth, a result indicating that different immigrant groups (by origin) can develop distinctly different labor and integration strategies. ${ }^{7}$

The next sections of this paper are intended to deepen our analysis of the spatial distribution of the internal mobility of immigrants. Reference will be made to the causes of this mobility emphasizing, as expected, many of the points raised in the preceding paragraphs. It should be noted on this point that the ENI does not enable us to compare immigrant mobility with that of natives, and thus this analysis is bound to be incomplete. The date of reference of the ENI, 1 January 2007, on the other hand, has both advantages and disadvantages. This date refers to a moment in the not so distant past that is much closer in time than that used by any other study of internal migration in Spain. On the other hand, however, it refers to a moment before the economic crisis that started in 2007 and has gather strength since then.

\footnotetext{
${ }^{5}$ The relationship between the accumulation of formal education and the propensity to move has the shape of an inverted $U$, in the sense that it is highest among persons with middle levels of education. In other words, when compared with immigrants with no education, the highest propensity to move is found among persons with a secondary education.

${ }^{6}$ The relationship between unemployment and internal mobility, while positive, is not statistically significant at the usual levels. In other studies of internal mobility undertaken by economists, this same result has been found with respect to native (non-immigrant) populations.

${ }^{7}$ The low levels of statistical significance of some of the variables mentioned, as well as others, such as Spanish citizenship, is explained by the authors in terms of the specific characteristics of the Spanish labor market.
} 


\section{SOCIODEMOGRAPHIC AND SPATIAL CHARACTERISTICS OF IMMIGRANTS: A BASIC COMPARISON OF MOBILE AND NON-MOBILE IMMIGRANTS}

Before embarking on an analysis of the spatial distribution and the internal mobility of immigrants, a few definitions are in order. Throughout this paper, the number of persons who move or migrate internally are those immigrants who declare that they have changed municipality of residence between their arrival in Spain and 2007 and that, therefore, have made at least one move within Spain. Persons who do not move internally are those who continue to live in the same municipality as when they arrived in the country. Those persons who have changed residence but who continue to live in the same municipality are not considered internal migrants in this paper. The basic database is made up of 15,465 individuals who at the time of the survey were under 65 years of age. The mobility analyzed here, therefore, can refer to movements that actually took place before the person was 16 years of age. ${ }^{8} \mathrm{In}$ this section, a basic comparison will be carried out between mobile and non-mobile immigrants (movers and non-movers). In so doing, mention will be made of earlier research on the subject.

Slightly more than one third of all immigrants $(38.5 \%$ of all persons included in the sample) had changed municipality of residence between the moment of arrival in Spain and 2007 (Reher et al. 2008: 99-100). The mean age of both mobile and non-mobile immigrants is 39 . Among non-movers, $43.9 \%$ are men and $56.1 \%$ women, while among movers the percentages are $46.4 \%$ and $53.6 \%$ respectively. The mean year of arrival for non-mobile immigrants is 1995 and for mobile ones it is 1991. These basic characteristics of immigrants, however, should be contextualized in terms of other factors that can affect the decision to move (Reher y Silvestre 2009). In this way, when analyzing the propensity to move internally within multivariate models, controlling for the effects of a series of variables (in order to test for the importance of any given theory), it can be seen that, for example, men are more likely to move than women (especially more than once).

In table 1, the difference between mobile and non-mobile immigrants is shown in terms of three basic characteristics of immigrants: world region of birth, their residence in 2007 and the type of municipality they lived in 2007. Each panel of the table is divided into two parts: one with percentages in rows and the other in columns. When analyzing the results corresponding to the world region of birth of the immigrant, it is evident that internal mobility among African immigrants is superior to other groups (lower part of the first panel). After Africans, once the heterogeneous group "Rest of the world" has been excluded, immigrants from Latin America show the highest levels of internal mobility. It is important to keep in mind that when using multivariate models, the highest levels

\footnotetext{
${ }^{8}$ All estimates have been made with both weighted and unweighted data, with similar results. In this article results based on unweighted data are used.
} 
Table 1.

Patterns of internal migration among immigrants (\%)

World region of birth

\begin{tabular}{lcccccc}
\hline & $\begin{array}{c}\text { Developed } \\
\text { Europe }\end{array}$ & $\begin{array}{c}\text { Rest of } \\
\text { Europe }\end{array}$ & Africa & $\begin{array}{c}\text { Latin } \\
\text { America }\end{array}$ & $\begin{array}{c}\text { Rest of the } \\
\text { world }\end{array}$ & Total \\
\hline Non-movers & 24.4 & 15.8 & 15.8 & 40.2 & 3.7 & 100 \\
Movers & 23.3 & 15.4 & 17.8 & 39.5 & 4.0 & 100 \\
Non-movers & 62.6 & 62.1 & 58.7 & 61.9 & 59.4 & 61.5 \\
Movers & 37.4 & 37.9 & 41.3 & 38.1 & 40.6 & 38.5 \\
Total & 100 & 100 & 100 & 100 & 100 & 100 \\
\hline
\end{tabular}

Macro-region of residence in 2007

\begin{tabular}{lcccccccc}
\hline & Madrid & Catalonia & Levante & Ebro Valley & South & North & $\begin{array}{c}\text { Canary } \\
\text { Islands }\end{array}$ & Total \\
\hline Non-movers & 12.5 & 11.8 & 24.7 & 13.0 & 16.9 & 16.7 & 4.4 & 100 \\
Movers & 11.6 & 11.7 & 23.1 & 15.2 & 15.2 & 19.0 & 4.3 & 100 \\
Non-movers & 63.3 & 61.7 & 63.0 & 57.7 & 63.9 & 58.5 & 62.3 & 61.5 \\
Movers & 36.7 & 38.3 & 37.0 & 42.3 & 36.1 & 41.5 & 37.7 & 38.5 \\
Total & 100 & 100 & 100 & 100 & 100 & 100 & 100 & 100 \\
\hline
\end{tabular}

Municipality of residence in 2007

\begin{tabular}{lccccc}
\hline & $\begin{array}{c}<10000 \\
\text { inhabitants }\end{array}$ & $\begin{array}{c}10000-50000 \\
\text { inhabitants }\end{array}$ & $\begin{array}{c}>50000 \\
\text { inhabitants }\end{array}$ & $\begin{array}{c}\text { Provincial } \\
\text { capital }\end{array}$ & Total \\
\hline Non-movers & 10.8 & 23.7 & 16.0 & 49.4 & 100 \\
Movers & 20.9 & 31.4 & 18.8 & 29.0 & 100 \\
Non-movers & 32.4 & 41.1 & 44.0 & 61.1 & 47.9 \\
Movers & 67.6 & 58.9 & 56.0 & 38.9 & 52.1 \\
Total & 100 & 100 & 100 & 100 & 100 \\
\hline
\end{tabular}

Notes: (1) "Movers" refers to those immigrants who have moved at least once within Spain; "Non-movers" refers to those who have not changed municipality of residence since arrival in Spain. (2) The first two rows (Non-movers and Movers) for each characteristic (place of origin, macro-region and municipality) should be read horizontally; while the rest of the rows (Non-movers, Movers and Total) for each characteristic should be read vertically. (3) With respect to the place of origin of immigrants and the region of residence in 2007, $\mathrm{N}=15,459$ (out of a total of 15,465 ). The difference is due to those immigrants who did not answer the questions or who did so incorrectly. (4) Developed Europe = Europe-14 (Austria, Belgium, Denmark, Finland, France, Germany, Greece, Ireland, Italy, Luxemburg, the Netherlands, Portugal, Sweden and the United Kingdom), Iceland, Liechtenstein and Norway; for the Rest of Europe, see note 9. (5) Macroregions: Madrid; Catalonia; Levante = Balearic Islands, Valencia, Murcia; Ebro Valley = Navarre, La Rioja, Aragon; South = Castilla-La Mancha, Extremadura, Andalusia, Ceuta, Melilla; North = Galicia, Asturias, Cantabria, Basque Country, Castilla-León; Canary Islands (6) For municipality of residence in 2007, $\mathrm{N}=11,438$ (out of a total of 15,465). (7) Please consult the text regarding the loss of information for this part of the table. Source: ENI-2007. 
of internal mobility are shown by immigrants from the "Rest of Europe", followed by Africans and, at a certain distance, by Latin Americans (Reher y Silvestre 2009). ${ }^{9}$

In the second panel of table 1, Spain has been subdivided into seven macro-regions based on the distribution of the immigrant stock (percentage of immigrants with respect to the total population) as shown by Recaño and Domingo (2006: 311). This distribution has enabled us to classify generally the region of current residence of all immigrants. A careful perusal of the data contained in the table shows that internal migrants in Madrid, Levante and the South tend to be redistributed towards other regions. In this way, taking the first two rows as an example, the value for "movers" for these macro-regions is clearly lower than for those who are "non movers". This difference suggests that the attraction of these regions for immigrants who move is lower than it is for those who do not. On the other hand, in the case of the third and fourth rows, the values for movers corresponding to these three regions are far from the values given for all immigrants (38.5\%). ${ }^{10}$ The North and the Ebro Valley, on the other hand, do not appear to be important places of residency upon arrival in Spain. In this way, in the first two rows, the value for movers for these two regions is higher than for non-movers. These differences indicate that these regions are more able to attract immigrants who have moved. With respect to rows three and four, the values for movers corresponding to these two regions are greater than for immigrants as a whole (38.5\%).

The last panel of table 1 reflects the size of the municipality of residence in 2007 and enables us to advance a bit more in this study of the spatial distribution of the immigrant population. ${ }^{11}$ The results appear to confirm the existence of an important process of redistribution of the immigrant population from provincial capitals to other types of municipality, especially the smaller ones. ${ }^{12}$ These and other related subjects will be analyzed in greater detail in the upcoming sections of this article.

\footnotetext{
${ }^{9}$ The rather generic category of Rest of Europe is made up of immigrants who come from countries not included in the category "Developed Europe" (see note 4 of table 1); in other words, people from Central and Eastern Europe. Romanians make up the majority of this group.

${ }^{10}$ On this subject, among others, see also Recaño (2002), García Coll (2005), Lamela (2006), Recaño and Domingo (2006), López Trigal (2008) and Reher and Silvestre (2009).

${ }^{11}$ In this classification, the category corresponding to municipalities $>50,000$ refers to municipalities that are not provincial capitals.

${ }^{12}$ There is a limitation to the information presented in this part of the table due to the way in which both the survey instrument and the way the database was created. It refers to the fact that it is not possible to analyze the patterns of mobility of those immigrants who have neither changed their place of residence (their house) nor their municipality of residence since arrival in Spain (4,019 in total). For this reason, the reader should be advised to take the results derived from this part of the table with considerable caution.
} 
Table 2.

Types of internal migration (\%)

World region of birth

\begin{tabular}{lcccc}
\hline & Within province & Within region & Inter-regional & Total \\
\hline Rest of Europe & 56.7 & 13.4 & 29.9 & 100 \\
Africa & 48.7 & 11.7 & 39.5 & 100 \\
Latin America & 56.5 & 9.6 & 33.9 & 100 \\
All movers & 56.3 & 11.3 & 32.5 & 100 \\
\hline
\end{tabular}

Education

\begin{tabular}{lcccc}
\hline & Within province & Within region & Inter-regional & Total \\
\hline No education & 53.8 & 14.0 & 32.2 & 100 \\
Primary education & 52.4 & 13.1 & 34.5 & 100 \\
Secondary education & 57.4 & 11.0 & 31.7 & 100 \\
Higher education & 57.5 & 9.6 & 32.9 & 100 \\
\hline
\end{tabular}

Notes: The total number of observations used for this table is 5,818 (of a possible total of 5,961). The regions used are the same ones used in the preceding section. "All movers" includes immigrants from Developed Europe and Rest of the world.

Source: ENI - 2007.

\section{INTERNAL MOBILITY AND THE CHARACTERISTICS OF ORIGINS AND DESTINATIONS}

In this section a different perspective will be used in order to examine in greater detail the basic characteristics of both the origin and the destination of immigrants who move at least once in Spain. As before, the period of reference for the data presented here continues to be the time between arrival in Spain and 2007. In order to simplify the presentation of results, we will concentrate on the three main groups of non-native immigrants in Spain: those coming from the Rest of Europe, Africa and Latin America.

Table 2 contains data regarding the type of migratory movement from a spatial standpoint: within any given province, within a region or between regions. The majority of internal moves undertaken by immigrants take place within single provinces $(56.3 \%$ ) (see the upper part of the table). This result is contrary to that found in some other studies where medium and long-distance internal migration appears to prevail (Recaño 2002; Recaño 
and Domingo 2006). ${ }^{13}$ In more detailed analysis not shown here it is apparent that these different patterns hardly vary by sex, age and year of arrival. ${ }^{14}$ The data presented in table 2 also show that long-distance internal migration is highest among native Africans, followed by Latin Americans. On the other hand, local movements within single provinces are most frequent among immigrants from the Rest of Europe and Latin America. It is also clear that moves within provinces are highest among persons with higher levels of education. ${ }^{15}$

If the perspective is based on the municipality of residence (table 3 ), once again a pattern of redistribution of immigrant population can be seen from provincial capitals toward smaller municipalities. This table shows the first municipality of residence and that of residence in 2007. It is interesting to note that internal immigrants living in provincial capitals go from nearly half in the municipality of origin to less than $30 \%$ in 2007 (first part of table 3). On the other hand, the second part of table 3 shows that, for example, nearly $40 \%$ of all immigrants who began residing in small villages and towns $(<10,000)$ and medium-sized municipalities $(10,000-50,000)$ continued to do so in $2007 .{ }^{16}$

Table 4 has a similar structure to table 3 , except that this time it shows the different types of municipality of residence of the main immigrant groups in Spain both upon arrival and in 2007. From the data presented here, it is clear that the pattern of redistribution from provincial capitals and large towns towards smaller ones $(<10,000)$ is greatest among immigrants from the Rest of Europe. ${ }^{17}$ When comparing the first place of residence and the residence in 2007, it is clear that there is a substantial increase among smaller municipalities (from $22.3 \%$ to $35.1 \%$ ) while among Africans and Latin Americans the increase is much smaller. Among these last two groups, the pattern of redistribution from provincial capitals is greater than among persons from the Rest of Europe, but the municipalities of destination are more diverse. ${ }^{18}$ It is interesting to note that the presence of persons from the Rest of Europe is much smaller in provincial capitals both at the outset of their stay in Spain and also in 2007.

\footnotetext{
${ }^{13}$ The fact that the dimensions of the regions used in this study differ should be kept in mind when interpreting results. In any case, short-distance movements tend to dominate among the entire internal migration population from the 1980s. For more on this subject, see, for example, Paluzie et al. (2009) and the bibliography cited therein.

${ }^{14}$ This information is available from the authors upon request.

${ }^{15}$ The ENI does not provide precise information regarding the amount of education acquired in Spain, but only whether or not a person had received some education in the host country. In any case, Fernández and Ortega (2008) have show that immigrants who were relatively old upon arrival had, in fact, very little education in the host society.

${ }^{16}$ In analysis not shown here, it can be seen that this pace of redistribution of the immigrant population appears to have accelerated since 2000 .

${ }^{17}$ On this point, see Camarero et al. (2009: 138).

${ }^{18}$ The number of available observations does not allow us to classify these patterns by levels of education.
} 
Table 3.

Types of internal migration by type of municipality (\%)

\begin{tabular}{|c|c|c|c|c|c|c|}
\hline & $<10000$ & $10000-50000$ & $>50000$ & Capital & Total \\
\hline \multicolumn{2}{|c|}{ Origin } & 17.2 & 20.7 & 14.7 & 47.4 & 100 \\
\hline \multicolumn{2}{|c|}{ Destination 2007} & 21.0 & 31.5 & 18.8 & 28.8 & 100 \\
\hline \multicolumn{7}{|c|}{ Destination in 2007} \\
\hline & & $<10000$ & $10000-50000$ & $>50000$ & Capital & Total \\
\hline \multirow{4}{*}{ 흠 } & $<10000$ & 39.7 & 28.0 & 9.0 & 23.3 & 100 \\
\hline & $10000-50000$ & 17.7 & 39.2 & 17.2 & 25.9 & 100 \\
\hline & $>50000$ & 15.7 & 28.8 & 28.2 & 27.3 & 100 \\
\hline & Capital & 17.2 & 30.2 & 20.1 & 32.4 & 100 \\
\hline
\end{tabular}

Note: $\mathrm{N}=5,808$.

Source: ENI-2007.

The data included in the lower half of each panel of table 4, which track individual patterns of origin and destination, once again show a pattern seen earlier of a tendency to reside in 2007 in the same type of municipality as the one of original residence. For example, table 4 shows that the propensity to reside in a provincial capital upon arrival in Spain and then again in 2007 is highest among Africans and Latin Americans (37.1\% and $33.1 \%$ respectively, as opposed to immigrants from the Rest of Europe). At the other end of the table, the propensity to reach a small town or village at the outset of their stay in Spain and in 2007 is higher for immigrants from the Rest of Europe (51.6\%, as opposed to $44.7 \%$ among Africans and $28.4 \%$ among Latin Americans). This pattern shown by immigrants from the Rest of Europe to either enter the lower end of the urban hierarchy (rural areas, small towns) directly or to move there from larger towns appears to be unique among immigrants to Spain and provides an interesting insight into their migratory strategies. It should be recalled here, that the data shown in this table are based only on immigrants who have made one or more internal move since arrival in Spain.

Table 5 reports the regional dimension of internal migration in Spain and has a similar structure to table 4. Table 5, for example, shows the role of Madrid in the redistribution of the immigrant population throughout Spain and the reduced importance of other regions as first places of residence..$^{19}$ In the upper part of the table, the reduction in the

\footnotetext{
${ }^{19}$ As opposed to the results shown in table 1, in table 5 (where only immigrants who move within Spain
} 
Table 4.

Types of internal migration by type of municipality and place of origin (\%)

Rest of Europe

\begin{tabular}{|c|c|c|c|c|c|c|}
\hline & & $<10000$ & $10000-50000$ & $>50000$ & Capital & Total \\
\hline & Origin & 22.3 & 29.1 & 13.9 & 34.7 & 100 \\
\hline & Destination 2007 & 35.1 & 28.5 & 13.3 & 23.1 & 100 \\
\hline \multicolumn{7}{|c|}{ Destination in 2007} \\
\hline & & $<10000$ & $10000-50000$ & $>50000$ & Capital & Total \\
\hline \multirow{4}{*}{ :응 } & $<10000$ & 51.6 & 25.6 & 4.0 & 18.8 & 100 \\
\hline & $10000-50000$ & 46.4 & 23.4 & 11.7 & 18.6 & 100 \\
\hline & $>50000$ & 18.0 & 28.1 & 24.5 & 29.5 & 100 \\
\hline & Capital & 21.9 & 34.9 & 16.1 & 27.1 & 100 \\
\hline
\end{tabular}

Africa

\begin{tabular}{|c|c|c|c|c|c|c|}
\hline & & $<10000$ & $10000-50000$ & $>50000$ & Capital & Total \\
\hline & Origin & 16.8 & 21.2 & 13.2 & 48.8 & 100 \\
\hline & Destination 2007 & 21.3 & 29.4 & 19.9 & 29.4 & 100 \\
\hline \multicolumn{7}{|c|}{ Destination in 2007} \\
\hline & & $<10000$ & $10000-50000$ & $>50000$ & Capital & Total \\
\hline \multirow{4}{*}{ 흫 } & $<10000$ & 44.7 & 28.8 & 6.5 & 20.0 & 100 \\
\hline & $10000-50000$ & 17.3 & 39.7 & 23.8 & 19.2 & 100 \\
\hline & $>50000$ & 12.8 & 24.1 & 34.6 & 28.6 & 100 \\
\hline & Capital & 17.2 & 26.6 & 18.9 & 37.3 & 100 \\
\hline
\end{tabular}

Latin America

\begin{tabular}{lccccc}
\hline & $<10000$ & $10000-50000$ & $>50000$ & Capital & Total \\
\hline Origin & 14.6 & 17.0 & 14.9 & 53.4 & 100 \\
Destination 2007 & 16.8 & 29.2 & 21.3 & 32.6 & 100 \\
\hline
\end{tabular}

Destination in 2007

\begin{tabular}{c|lccccc}
\hline & & $<10000$ & $10000-50000$ & $>50000$ & Capital & Total \\
\hline \multirow{5}{*}{ 흫 } & $<10000$ & 28.4 & 28.4 & 11.9 & 31.3 & 100 \\
& $10000-50000$ & 14.4 & 34.6 & 17.4 & 33.6 & 100 \\
& $>50000$ & 12.9 & 25.4 & 30.4 & 31.3 & 100 \\
& Capital & 15.6 & 28.8 & 22.5 & 33.1 & 100 \\
\hline
\end{tabular}

Nota: $\mathrm{N}=5,818$. Source: ENI-2007. 
importance of Madrid as place of residence between arrival in Spain and 2007 is clear (from $19.6 \%$ to $11.7 \%$ ) The importance of Madrid as a source of population redistribution is probably the result of its role the main point of entry into the country rather than to its ability to attract internal migrants. It should also be recalled that Madrid is a region made up of a single province as opposed to the other regions used in this study that are multi-provincial. ${ }^{20}$

The second part of table 5 confirms these results but adds further dimensions to our analysis. In this part of the table the pattern of movement within a single region is shown quite clearly. This result is not surprising in the light of earlier results showing the importance of this type of mobility. Again it is clear how Madrid tends to redistribute the immigrant population throughout Spain but especially towards the regions of the Levante, the South and the North. Conversely, Madrid receives very little population from other regions of Spain. Catalonia, for example, exports population to the Levante and to the Ebro Valley. A different pattern can be seen in the Levante that receives immigrant population from other regions but hardly send out immigrants at all. There are almost no exchanges between Catalonia and Madrid. These results offer additional proof that internal migration is a more complex and layered phenomenon than might have been imagined.

Table 5.

Types of internal migration by region of residence (\%)

\begin{tabular}{lcccccccc}
\hline & Madrid & Catalonia & Levante & Ebro V. & South & North & Canaries & Total \\
\hline Origin & 19.6 & 12.7 & 18.8 & 10.0 & 16.0 & 18.8 & 4.1 & 100 \\
Destination 2007 & 11.7 & 11.4 & 23.1 & 15.2 & 15.4 & 19.0 & 4.3 & 100 \\
\hline
\end{tabular}

Destination in 2007

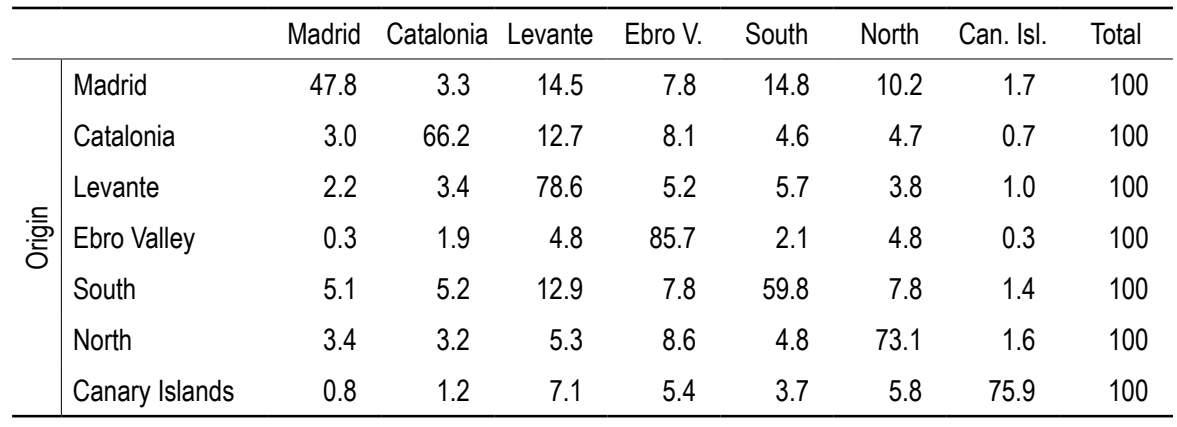

Nota: $\mathrm{N}=5,818$. Source: $\mathrm{ENI}-2007$.

are included), it can be seen that the Levante region is an important source of attraction for immigrants. This result appears to point to the importance of intra-regional mobility in this región.

${ }^{20}$ The data included in this table refer only to mobile immigrants, and does not include immigrants who have not changed municipality of residence since arrival in Spain. 


\section{REPEAT INTERNAL MIGRATION}

Up until this point, the main characteristics of internal migration have been analyzed only in terms of the first place of residence in Spain after arrival and residence in 2007, the date of the survey. In this section, a new dimension of internal migration will be shown, one which includes repeated or multiple movements within the country. For those immigrants moving only once, the data shown thus far tells the entire story. It does not, however, for those who have moved more than once. Of all immigrants present in Spain, including both movers and non-movers, $16 \%$ of them have moved more than once since they arrived in the country (Reher, et al. 2008: 99).

In table 6, the importance of these multiple moves is shown among all immigrants moving at least once. Of them, just under one half (41.5\%) have moved more than once. If moves are shown by region of origin, repeated movement is most frequent among

Table 6.

Patterns of repeat internal migration among immigrants moving at least once (\%)

All immigrants

\begin{tabular}{|c|c|c|c|c|}
\hline & Rest of Europe & Africa & Latin America & All movers \\
\hline \multicolumn{5}{|c|}{ Number of moves } \\
\hline 1 & 64.4 & 50.8 & 59.1 & 58.5 \\
\hline 2 & 25.1 & 26.4 & 26.9 & 25.5 \\
\hline 3 & 6.4 & 10.9 & 8.8 & 8.8 \\
\hline 4 & 2.3 & 5.9 & 3.2 & 3.8 \\
\hline 5 and more & 1.7 & 5.9 & 2.0 & 3.4 \\
\hline Total & 100 & 100 & 100 & 100 \\
\hline \multicolumn{5}{|c|}{ Immigrants arriving after 2000} \\
\hline & Rest of Europe & Africa & Latin America & All movers \\
\hline \multicolumn{5}{|c|}{ Number of moves } \\
\hline 1 & 67.0 & 55.3 & 62.7 & 63.9 \\
\hline 2 & 24.1 & 25.2 & 26.0 & 24.8 \\
\hline 3 & 5.0 & 10.0 & 7.7 & 6.9 \\
\hline 4 & 2.6 & 5.5 & 2.3 & 2.8 \\
\hline 5 and more & 1.3 & 4.0 & 1.3 & 1.6 \\
\hline Total & 100 & 100 & 100 & 100 \\
\hline
\end{tabular}

Notes: Fort the upper part of the table $N=5,955$, and for the lower part $N=2,634$. "All movers" includes immigrants coming from Developed Europe and from the Rest of the world.

Source: ENI-2007. 
Africans and less so for immigrants from the other two regions used in this analysis (Latin America and the Rest of Europe). ${ }^{21}$ In the results shown in the second part of the table only immigrants arriving in Spain in 2000 or more recently are used in order to see the extent to which the duration of their stay in the country influences our findings. The results in both parts of the table, however, are similar. The observed patterns of mobility do not appear to be a function of when the immigrants arrived in the country or the duration of their stay.

There are different ways of analyzing repeated internal migration. In the rest of this section only three of its characteristics will be considered: the mean duration of the immigrant's stay in any given destination, the characteristics of the point of departure and the destination of each move, and cases when the immigrants returns to their point of departure within Spain (return internal migration). ${ }^{22}$ As Martí and Ródenas (2008) point out (2008), the analysis of repeat internal migration is important because this type of mobility could be the consequence of the process of job seeking, but it also might lead to a loss of economic status. The number of classification categories used here will be relatively few because there are simply not enough observations available to disaggregate any further.

A unique aspect of the National Immigrant Survey is that it enables us to assess the duration of each stay in each destination. These data are shown in table 7 for each destination (the upper part of the table) and for the total number of moves an immigrant has made. Two important conclusions can be derived from these results. On the one hand, the mean duration at each destination appears to depend more on the world region of birth of the immigrant than on the number of moves he or she has made ${ }^{.23}$ In other words, the mean duration of each stay in each destination does not appear to vary as much by the number of destination (first, second, third, etc), as it does by the world region of birth. ${ }^{24}$ Secondly, immigrants from the Rest of Europe are characterized by much shorter stays than immigrants from other origins. The mean duration of the stays of immigrants from the Rest of Europe tends to be less than half what it is for immigrants from the other two origins shown in the table. ${ }^{25}$

\footnotetext{
${ }^{21}$ The importance of repeat immigration among African immigrants is also confirmed by the econometric estimates included in Reher and Silvestre (2009).

${ }^{22}$ In a different paper (in progress), an in-depth analysis of repeat internal migration and its characteristics is undertaken.

${ }^{23}$ These estimates have also been generated for immigrants from Developed Europe. Results not shown here reveal that the duration of the stays for immigrants from Developed Europe tends to diminish rather clearly as the number of each move increases. The mean duration in each destination is also greater among immigrants in this group than it is for the other groups. These results are probably the result of the fact that internal movement among them is less linked to work and job-seeking than it is among other groups.

${ }^{24}$ Bear in mind that people compared here have made a different total numbers of moves during their stay in Spain. See also the notes to table 7.

${ }^{25}$ It should be noted that the very high duration of stays for All movers is because this last category includes immigrants from Developed Europe.
} 
Table 7.

Mean duration of stay in each destination (months)

\begin{tabular}{|c|c|c|c|c|c|}
\hline & & Rest of Europe & Africa & Latin America & All movers \\
\hline \multirow{7}{*}{ 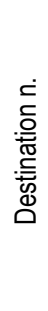 } & 1 & 21.5 & 51.1 & 41.0 & 54.3 \\
\hline & 2 & 33.7 & 69.4 & 56.4 & 71.2 \\
\hline & 3 & 32.0 & 67.5 & 54.4 & 64.6 \\
\hline & 4 & 27.8 & 60.2 & 52.6 & 59.1 \\
\hline & 5 & 19.3 & 59.0 & 61.7 & 60.3 \\
\hline & 6 & 19.6 & 45.3 & 73.0 & 63.3 \\
\hline & 7 & 24.0 & 43.8 & 56.8 & 51.0 \\
\hline \multirow{4}{*}{$\begin{array}{l}\stackrel{\complement}{\mathbb{\varpi}} \\
\sum\end{array}$} & $1-4$ & 28.8 & 62.1 & 51.1 & 62.3 \\
\hline & $1-5$ & 26.9 & 61.4 & 53.2 & 61.9 \\
\hline & $1-6$ & 25.7 & 58.8 & 56.5 & 62.1 \\
\hline & $1-7$ & 25.4 & 56.6 & 56.6 & 60.5 \\
\hline
\end{tabular}

Notes: Number of observations: destination $1=5,851$; destination $2=5,786$; destination $3=2,398$; destination $4=905$; destination 5 = 396; destination $6=186$; destination $7=89$. "All movers" also includes immigrants from Developed Europe and the Rest of the world.

Source: ENI-2007.

In table 8 repeated internal migration is classified by the spatial dimensions of each movement (within the province, within the region and inter-regional). Because of limited numbers, here only three movements have been included. When looking at all movers, movements within the province appear to be more important for the initial move than for subsequent ones. This indicates that immigrants tend to move first to nearby areas, and only then begin to extend the spatial scope of their migration trajectory. In accord with results presented earlier, when disaggregating by origin Africans appear as the group most likely to move longer distances, a pattern that appears to increase as the number of moves increases. On the other hand, long-distance moves appear to be much less likely among immigrants from the Rest of Europe than they are for other groups.

Table 9 shows the existence of a process of redistribution of the immigrant population from provincial capitals towards smaller municipalities, thus confirming the results on this subject presented in tables 3 and 4 of this paper. Here the subject has been shown in terms of the each successive internal move. Provincial capitals lose immigrant population in each of the moves shown in the table. On the contrary, smaller $(<10,000)$ and medium-sized municipalities $(10,000-50,000)$ tend to gain immigrant population.

The issue of return internal migration is addressed in table 10 with is based on immigrants who have made two or more internal moves (and thus are candidates to return 
Table 8.

Repeat internal migration by pattern of movement and origin (\%)

All movers

\begin{tabular}{|c|c|c|c|c|c|}
\hline & & Within province & Within region & Inter-regional & Total \\
\hline \multirow{3}{*}{$\stackrel{0}{D}$} & $1 \rightarrow 2$ & 52.2 & 13.1 & 34.7 & 100 \\
\hline & $2 \rightarrow 3$ & 49.4 & 14.6 & 36.0 & 100 \\
\hline & $3 \rightarrow 4$ & 44.9 & 16.5 & 38.7 & 100 \\
\hline
\end{tabular}

Rest of Europe

\begin{tabular}{|c|c|c|c|c|c|}
\hline & & Within province & Within region & Inter-regional & Tota \\
\hline \multirow{3}{*}{$\stackrel{0}{2}$} & $1 \rightarrow 2$ & 53.6 & 15.1 & 31.3 & 100 \\
\hline & $2 \rightarrow 3$ & 52.8 & 18.4 & 28.8 & 100 \\
\hline & $3 \rightarrow 4$ & 53.2 & 18.1 & 28.7 & 100 \\
\hline
\end{tabular}

Africa

\begin{tabular}{|c|c|c|c|c|c|}
\hline & & Within province & Within region & Inter-regional & Total \\
\hline \multirow{3}{*}{$\stackrel{0}{\stackrel{0}{\Sigma}}$} & $1 \rightarrow 2$ & 43.9 & 14.6 & 41.5 & 100 \\
\hline & $2 \rightarrow 3$ & 39.5 & 15.3 & 45.2 & 100 \\
\hline & $3 \rightarrow 4$ & 36.4 & 17.4 & 46.3 & 100 \\
\hline
\end{tabular}

Latin America

\begin{tabular}{|c|c|c|c|c|c|}
\hline & & Within province & Within region & Inter-regional & Tota \\
\hline \multirow{3}{*}{$\stackrel{0}{\text { Do }}$} & $1 \rightarrow 2$ & 52.2 & 11.1 & 36.7 & 100 \\
\hline & $2 \rightarrow 3$ & 51.6 & 12.8 & 35.6 & 100 \\
\hline & $3 \rightarrow 4$ & 51.0 & 14.3 & 34.7 & 100 \\
\hline
\end{tabular}

Notes: "All movers" includes immigrants from Developed Europe and from the Rest of the world. Number of observations: All movers, first, second and third movement $=5,945,2,508$ y 965 . Rest de Europe, first, second and third movement $=916,326$ y 94 . Africa, first, second and third movement $=1,060,531$ y 242. Latin America, first, second and third movement $=2,346,979$ y 343. Source: ENI-2007.

to their point of departure). The results show that this type of internal migration pattern is chosen by slightly more than one quarter of all immigrants (27.1\%) who are multiple movers. The incidence of return movement is higher among Latin Americans than among the other immigrant groups shown in the table. ${ }^{26}$

${ }^{26}$ Differences by current age or by the date of arrival in Spain (not shown here) are not significant. Return internal migration is more common among men (51\%). 
Table 9.

Repeat internal migration by type of municipality (\%)

\begin{tabular}{|c|c|c|c|c|c|}
\hline & $<10000$ & $10000-50000$ & $>50000$ & Capital & Total \\
\hline \multicolumn{6}{|l|}{ Move $1 \rightarrow 2$} \\
\hline Origin & 17.2 & 20.9 & 14.6 & 47.3 & 100 \\
\hline Destination & 19.8 & 28.6 & 19.4 & 32.2 & 100 \\
\hline \multicolumn{6}{|l|}{ Move $2 \rightarrow 3$} \\
\hline Origin & 19.1 & 24.8 & 18.1 & 38.1 & 100 \\
\hline Destination & 20.9 & 27.9 & 16.2 & 35.0 & 100 \\
\hline \multicolumn{6}{|l|}{ Move $3 \rightarrow 4$} \\
\hline Origin & 20.4 & 21.6 & 14.7 & 43.3 & 100 \\
\hline Destination & 22.5 & 26.9 & 13.8 & 36.8 & 100 \\
\hline \multicolumn{6}{|l|}{ Move $4 \rightarrow 5$} \\
\hline Origin & 23.9 & 24.6 & 10.2 & 41.4 & 100 \\
\hline Destination & 20.3 & 29.6 & 13.5 & 36.6 & 100 \\
\hline
\end{tabular}

Notes: Number of observations: move $1 \rightarrow 2=5,931$; move $2 \rightarrow 3=2,501$; move $3 \rightarrow 4=963$; move $4 \rightarrow 5=423$. Source: ENI-2007.

Table 10.

Return internal migration among immigrants who move (\%)

\begin{tabular}{lcccc}
\hline & Rest of Europe & Africa & Latin America & All movers \\
\hline Return to point of departure & 23.2 & 23.6 & 29.9 & 27.1 \\
Move on to another destination & 76.8 & 76.4 & 70.1 & 72.9 \\
Total & 100 & 100 & 100 & 100 \\
\hline
\end{tabular}

Note: $\mathrm{N}=2,500$. "All movers" includes immigrants from Developed Europe and from the Rest of the world. Source: ENI-2007. 


\section{Conclusions}

Spain has become an important destination point for international migration in recent years. In this paper internal migration, an important aspect of immigration in host societies, has been analyzed. The study of the spatial distribution of immigrants and of their internal movement is important for the design of economic, social and demographic policy, as well as for a better understanding of the basic migratory process. The analysis developed here has made ample use of the microdata generated by the National Immigrant Survey (ENI-2007).

Among the most noteworthy results of this study is the fact that it has been shown that more than one third of all immigrants have changed the municipality of residence between the time of their arrival and 2007, the date of the ENI. A preliminary descriptive analysis of internal mobility shows that it is more important among women than among men, as well as among immigrants who are natives of Africa. Nevertheless, when these initial results are seen within the context of multivariate models, men — rather than women — and immigrants from the Rest of Europe-, together with African immigrants, have been shown to have a higher propensity towards this type of movement. Short-distance internal migration tends to predominate here, with movements within any given province representing more than half of all moves. It is interesting to note that intra-provincial movement is highest among the more educated. All of these points, especially the last one, deserve more attention.

Secondly, the results shown here have highlighted an important process of spatial redistribution of the immigrant population from provincial capitals towards smaller towns, a pattern that appears to have accelerated in recent years. This phenomenon has important policy implications for Spain (Collantes et al. 2010). The results of this study have also shown important redistribution processes especially from Madrid, the entry point to Spain for a large percentage of immigrants, towards other regions of the country. The migratory exchanges between other regions used in this study have also been shown to be important. Despite this, this study has also shown that there is a significant tendency for mobile immigrants to move to municipalities of a similar size or type (say, provincial capitals) or within given provinces. ${ }^{27}$

In the third place, the spatial redistribution of the immigrant population is sometimes achieved by means of successive migratory moves, thus indicating the existence of a process of whereby the most suitable destination is reached step by step. Approximately one in six immigrants resident in Spain has moved more than once within the country, and this proportion exceeds $40 \%$ if we only consider immigrants who have moved at least once. Among these multiple movers, it is also worth mentioning that no small percentage of them who return to their original destination in Spain. Approximately one in four of them can be classified as return internal migrants.

\footnotetext{
${ }^{27} \mathrm{An}$ empirical analysis of this issue (in progress), reveals a more complex process than simple bivariate analysis would suggest.
} 
Finally, our analysis of internal mobility of immigrants in terms of their world region of birth has shown results that may be also relevant for migration policy in Spain. In this way, the process of redistribution of the immigrant population towards small municipalities appears to be much more frequent among immigrants coming from the Rest of Europe (mainly natives of Romania). The intensity of this process does not appear to be matched in any other immigrant group. Among African immigrants, long-distance (inter-regional) internal migration tends to prevail. Besides, Africans are also the group that shows the highest propensity towards internal mobility (nevertheless, as mentioned above, when these patterns are analyzed within multivariate models, immigrants from the Rest of Europe show the highest levels of internal mobility). The mean duration of stays in each destination among African immigrants is also the highest in comparison with the two other immigrant groups, but indeed shorter than among immigrants from Developed Europe. The levels shown by immigrants from Latin America tend to be similar to those of the immigrant population as a whole. Nevertheless, this group is the one that shows the highest levels of return internal migration within Spain.

The findings shown in this study are the result of a preliminary approach to this fascinating, but relatively little known and complex subject. Despite some noteworthy research, it continues to lack a sufficient "density" of research to enable us to elaborate solid interpretive hypotheses, at least insofar as some of its aspects are concerned. A glaring example of this is the case of repeat migration which continues symbolically "off limits" in most countries. Other types of approach, including econometric studies, are required. The importance of the processes highlighted here with respect to social and economic mobility of the immigrants themselves, as well as for migration policies, is evident.

\section{REFERENCES}

Alba, R. and V. Nee. 1997. "Rethinking Assimilation Theory for a New Era of Immigration." International Migration Review 31 (4): 826-874.

Arango, J. 2004. "La inmigración en España a comienzos del siglo XXI." Pp. 161-186 in Informe sobre la situación demográfica en España, edited by J. Leal. Madrid: Fundación Abril Martorell.

Bartel, A. P. 1989. "Where Do the New U.S. Immigrants Live?." Journal of Labor Economics 7 (4): 371-391.

Cachón, L. 2006. "Los inmigrantes en el mercado de trabajo en España (1996-2004)." Pp. 175-201 in Veinte años de inmigración en España. Perspectivas jurídica y sociológica [1985-2000], edited by E. Aja and J. Arango. Barcelona: Fundación CIDOB.

Camarero, L., F. Cruz, M. González, J. A. Del Pino, J. Oliva and R. Sampedro 2009. La población rural en España. De los desequilibrios a la sostenibilidad rural. Barcelona: Fundación La Caixa.

Collantes, F., V. Pinilla, L. A. Sáez and J. Silvestre. 2010. El impacto demográfico de la inmigración en la España rural despoblada. Madrid: Documento de Trabajo del Real Instituto Elcano. 
Dolado, J. J. and P. Vázquez. 2007. "Los efectos económicos y las políticas de la inmigración: panorámica y reflexiones." Pp. 6-25 in Ensayos sobre los efectos económicos de la inmigración en España. Ed. J. J. Dolado and P. Vázquez. Madrid: FEDEA.

Fernández, C. and C. Ortega. 2008. "Labor market assimilation of immigrants in Spain: employment at the expense of bad job-matches." Spanish Economic Review 10 (2): 83-107.

García Coll, A. 2005. "Migraciones interiores y transformaciones territoriales." Papeles de Economía Española 104: 76-91.

Chiswick, B. R. and P. W. Miller. 2004. "Where Immigrants Settle in the United States." Journal of Comparative Policy Analysis: Research and Practice 6 (2): 185-197.

Hooghe, M., Trappers, A., Meuleman, B. and T. Reeskens. 2008. "Migration to European Countries: A Structural Explanation of Patterns, 1980-2004." International Migration Review 42 (2): 476-504.

Iceland, J. 2009. Where We Live Now. Immigration and Race in the United States. Los Angeles and Berkeley: University of California Press.

Internacional Organization for Migration. 2008. World Migration 2008. Managing Labour Mobility in the Evolving Global Economy. Geneva: IOM.

Izquierdo, A. 1996. La inmigración inesperada. Madrid: Trotta.

Lamela, C. 2006. "Migración interna de los extranjeros." Pp. 238-266 in Demografía de los extranjeros. Incidencia en el crecimiento de la población, edited by A. Izquierdo. Bilbao: Fundación BBVA.

López Trigal, L. 2008. "La desigual distribución de la inmigración en España. Una exploración de las regiones interiores y atlánticas peninsulares." Pp. 93-109 in La inmigración en la sociedad española. Una radiografía multidisciplinar, edited by A. García Roca and J. Lacomba. Barcelona: Edicions Bellaterra.

Martí, M. and C. Ródenas. 2008. "Reemigrar en España: una aproximación a sus determinantes." Paper presented at the XI Encuentro de Economía Aplicada, Salamanca, 5-7 June.

Martínez Buján, R. and M. Villares. 2006. "Contextos de llegada e instalación." Pp. 137-235 in Demografía de los extranjeros. Incidencia en el crecimiento de la población, edited by A. Izquierdo. Bilbao: Fundación BBVA.

Massey, D. S. 1985. "Ethnic Residential Segregation: A Theoretical Synthesis and Empirical Review." Sociology and Social Research, 69 (3): 315-350.

Massey, D., S. Arango, G. Hugo, A. Kouaouci, A. Pellegrino and E. Taylor. 1998. Worlds in Motion. Understanding International Migration at the End of the Millenium. Oxford: Oxford University Press.

Nogle, J. M. 1994. "Internal Migration for Recent Immigrants to Canada." International Migration Review 28 (1): 31-48.

Paluzie, E., J. Pons, J. Silvestre and D. Tirado. 2009. "Migrants and market potential in Spain over the twentieth century: a test of the new economic geography." Spanish Economic Review 11: 243-265. 
Portes, A. 1995. "Economic Sociology and the Sociology of Immigration: A Conceptual Overview." Pp. 1-41 in The Economic Sociology of Immigration. Essays on Networks, Ethnicity and Enterpreneurship, edited by A. Portes. New York: Russell Sage Foundation.

Recaño, J. 2002. "La movilidad geográfica de la población extranjera en España: un fenómeno emergente." Cuadernos de Geografía 72: 135-156.

Recaño, J. 2004. "Migraciones internas y distribución espacial de la población española." Pp. 187-228 in Informe sobre la situación demográfica en España, edited by J. Leal. Madrid: Fundación Abril Martorell.

Recaño, J. 2008. "Las migraciones internas de la población extranjera en España: factores sociodemográficos e implicaciones territoriales." Paper presented at the Seminario de la Fundación BBVA -Ivie, Madrid, 24 January.

Recaño, J. and A. Domingo. 2006. "Evolución de la distribución territorial y la movilidad geográfica de la población extranjera en España." Pp. 303-338 in Veinte años de inmigración en España. Perspectivas jurídica y sociológica [1985-2004], edited by E. Aja and J. Arango. Barcelona: Fundación CIDOB.

Recaño, J. and M. Roig. 2006. "The internal migration of foreigners in Spain." Paper presented at the 2006 European Population. http://epc2006. princeton.edu/download. aspx?submissionld=60411.

Reher, D.S., L. Cortés-Alcalá, F. González-Quiñones, M. Requena, M. Sánchez-Dominguez, A. SanzGimeno and M. Stanek. 2008. Informe Encuesta Nacional de Inmigrantes (ENI-2007). Madrid: Instituto Nacional de Estadística. Available at http://www.ine.es/inebmenu/mnu_migrac.htm\#2.

Reher, D.S. and. M. Requena. 2009. "The National Immigrant Survey of Spain. A rich new data source for migration studies in Europe." Demographic Research 20: 253-278.

Reher, D. S. y J. Silvestre. 2009. "Internal Migration Patterns of Foreign-Born Immigrants in a Country of Recent Mass Immigration: Evidence from New Micro Data for Spain." International Migration Review 43(4): 815-849.

Ródenas, C. and M. Martí. 2006. "Reinterpretando el crecimiento de la movilidad en España: la población extranjera y las migraciones repetidas." Cuadernos Aragoneses de Economía 16 (1): 37-59.

United Nations. 2006. International Migration 2006. New York: UN Population Division. Available at http://www.un.org/esa/population/publications.

Venturini, A. 2004. Postwar Migration in Southern Europe, 1950-2000. Cambridge: Cambridge University Press.

DAVID REHER is Professor (Catedrático) of Sociology at the Universidad Complutense de Madrid. He is a founding member of the Asociación de Demografía Histórica (ADEH), Vice-President and President of the ADEH, Chair of the Historical Demography Committee of the International Union for the Scientific Study of Population (IUSSP), Director of the Grupo de Estudios Población y Sociedad (GEPS) and Principal Investigator of the research team that originally proposed the National Immigrant Survey and carried it out in collaboration with the Spanish Statistical Office (Instituto Nacional de Estadística - INE). $\mathrm{He}$ is author of numerous books, book chapters and scientific articles in the fields of demography, population history and the history of the family. 
JAVIER SILVESTRE is associate professor of economic history at the University of Zaragoza. His recent work in the field of migrations has been published in International Migration Review, Spanish Economic Review, Historia y Política, and The Journal of Historical Geography. His most recent research in the field of workplace safety has been published in Business History Review. He is also the co-editor of a book on the origins of the Welfare State in Spain (Los origenes del Estado del Bienestar en España, 1900-1945. Los seguros de accidentes, vejez, desempleo y enfermedad. Zaragoza: Prensas Universitarias de Zaragoza, 2010).

RECEIVED: 03/11/2010

ACCEPTED: $17 / 01 / 2011$ 